\title{
An Exhibitor Wants Increased Visibility or Susan Makes Bobby's Head Ache
}

\author{
By Andrew R. J. Yeaman, Column Editor
}

(C)Association for Educational Communications and Technology 2015

\section{Scenario}

Chan was the incoming president of her state's association for libraries, media, and technology. The position traditionally encompassed responsibility for conference organizing. Twenty years earlier, Susan had been appointed the full-time staff executive managing the association. She successfully balanced the duties with running her own small business. Chan was assured $\mathrm{Su}-$ san's office would handle the myriad minor decisions. Nonetheless, Chan would be informed when there was something important such as selecting keynote speakers. For several months planning progressed smoothly, as it had for as long as anyone could remember.

When Bobby, a corporate vice president and regional sales manager for OntiX, called to arrange their regular get together Chan did not know they would have a reservation at the Sky Room. It was the best restaurant in town with $360^{\circ}$ views from the top of the tallest building. Chan was glad to be honored but not surprised, having heard this sort of thing happened. Also, she felt secure in herself in that nobody-not even Bobby who had become a personal friend-could unduly influence her.

In the comfort and privacy of the Sky Room Bobby spoke about trends developing, new products being tested, and her excitement over the company's expansion across state lines including the name change from OntiX to OntiX Learning. Then she explained her boss instructed her to arrange for a large booth next to the registration desk in the conference lobby matching the one set up every year by AVidity Systems.

Chan responded, "Sounds fine to me although prime real estate costs extra. Just give Susan your requirements."

"That's just it. Susan says no way.
The only vendor allowed in the lobby is AVidity."

"Only?"

Bobby spoke reluctantly, almost inarticulate with hesitations. "She said it's a matter of space-but I don't believe that for a minute-and a longstanding arrangement with AVidity hosting the Friday reception. Then I told her, 'Look, OntiX has grown. How about if my boss supports a reception on another night-or a luncheon-and donates to the scholarship fund?' And still Susan's answer was no. Well...this favoritism is simply not right."

Chan nodded as if to say "I heard you' and looked away to contemplate the sunset. Chan realized that holding an elected office is more involving and less ceremonial that it had seemed. She remembered there is a relevant ethical principle. It is up to her to use the principle as a tool for investigating and resolving the complaint.

\section{Principle}

\section{AECT Code of Professional Ethics}

\section{Section 2 - Commitment to Society Principle 5}

In fulfilling obligations to society, the member:

Shall engage in fair and equitable practices with those rendering service to the profession.

(Apply the principle to the scenario for yourself before going on to read the analysis.)

\section{Notes}

The Professional Ethics scenarios published in TechTrends are fictitious (see TechTrends, March-April, 2006, pp. 10-11). There is no intentional resemblance to specific people or particular organizations. The instructional purpose is to raise consciousness about AECT's Code of Professional Ethics.

\section{Analysis}

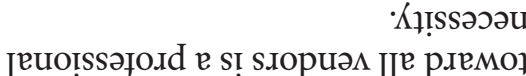

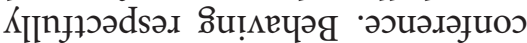

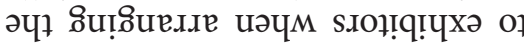

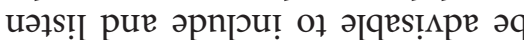

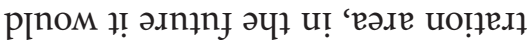

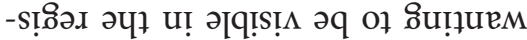

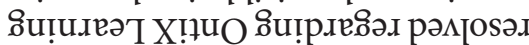

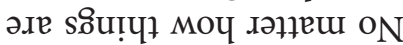

-рәріоле

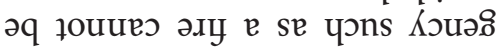

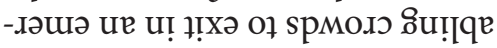

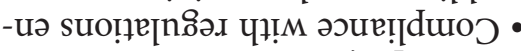
рәКордшә әq

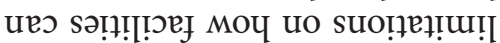
วsodu! Keu səpos Kұ! ou!pnp

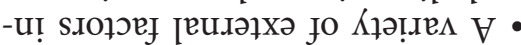
Кำ!

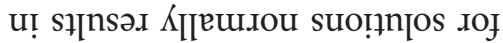
sıә8виеш 8и!уse 'тәләмоН 'sеә

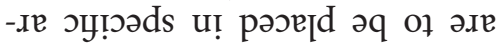
sәवет КUеш моч pue 'Mоч 'Uәчм 'әләчм .

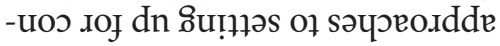

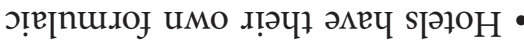
'sə8ิuey

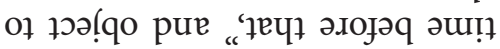

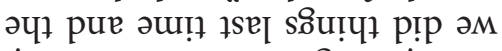

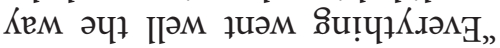

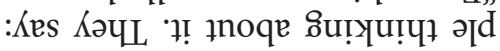

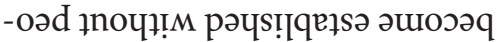

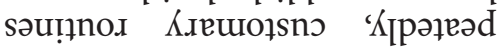
-әл рГәч s! әәиәдәјио $\mathfrak{e}$ шәчM •

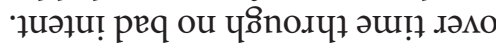

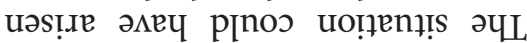

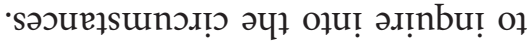
spәәu II!̣s uечว 'suәəs

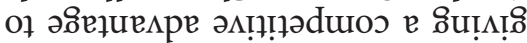

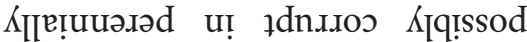
pue paseịq s! uesns łeчt pəou!̣

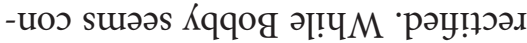
әq of Kұ!nbəu! ue әq 'pәәрu! 'Кeu әләц

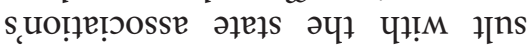

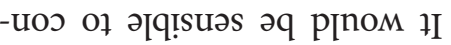

